\title{
OTOLITH GROWTH AND AGE ESTIMATION OF BASTARD GRUNT, POMADASYS INCISUS (ACTINOPTERYGII: PERCIFORMES: HAEMULIDAE), IN THE GULF OF TUNIS (CENTRAL MEDITERRANEAN)
}

\author{
Inès CHATER ${ }^{1 *}$, Ahlem ROMDHANI ${ }^{1}$, Jean Louis DUFOUR ${ }^{2}$, Kélig MAHE $^{2}$, \\ Patrice FRANCOUR ${ }^{3}$, and Nadia CHAKROUN-MARZOUK ${ }^{1}$ \\ ${ }^{1}$ Department of Biology, Faculty of Sciences of Tunis, Tunisia \\ ${ }^{2}$ French Research Institute for Exploitation of the Sea (IFREMER) Boulogne-sur-Mer, France \\ ${ }^{3}$ Nice-Sophia Antipolis University, Faculty of Sciences, ECOMERS, France
}

\begin{abstract}
Chater I., Romdhani A., Dufour J.L., Mahé K., Francour P., Chakroun-Marzouk N. 2015. Otolith growth and age estimation of bastard grunt, Pomadasys incisus (Actinopterygii: Perciformes: Haemulidae), in the Gulf of Tunis (Central Mediterranean). Acta Ichthyol. Piscat. 45 (1): 57-64.
\end{abstract}

Background. Bastard grunt, Pomadasys incisus (Bowdich, 1825), is reported as a well-established species in the Mediterranean Sea. Although bastard grunt has rapidly expanded its area of distribution in the Mediterranean, there is no information about its age and growth. The aim of this study was to provide data about growth, condition, and first sexual maturity of the species in order to contribute to a better management of its fishery.

Materials and methods. A total of 515 specimens of bastard grunt were caught in the Gulf of Tunis. The age was determined from otoliths. Length-weight relation, von Bertalanffy equation, and growth rate were employed to evaluate the fish growth. Also the condition factor and length at first sexual maturity were calculated.

Results. In the Gulf of Tunis population, females were significantly predominant and the overall sex ratio (M : F) reached the value of $1: 2.17$. The two sexes showed a positive allometric growth. The marginal increment analysis validated the annual deposition of one single annulus in the winter. Growth in (total) length (TL) was approximately $65 \%$ during the first year of life. The von Bertalanffy growth equation was TL $=23.9 \times\left(1-e^{-0.186 \times(t+4.62)}\right)$. The somatic condition of fish increased markedly during the late spring and summer. Length at first sexual maturity of the bastard grunt was $16.6 \mathrm{~cm}$ for males and $16.8 \mathrm{~cm}$ for females, which correspond to an age of about 2 years.

Conclusion. The rapid growth during the first year of life, the early maturity and the moderately short life cycle contribute to the relatively fast spreading of the species.

Keywords: sagittal otoliths, biological traits, von Bertalanffy growth function, length-weight relation, Pomadasys incisus

\section{INTRODUCTION}

The bastard grunt, Pomadasys incisus (Bowdich, 1825 ), is one of the five species belonging to the family Haemulidae, recorded in the Mediterranean Sea (Froese and Pauly 2014). It is a coastal, thermophilic, and demersal species inhabiting inshore marine waters down to 100 $m$ depth on sandy or rocky bottoms, common in the eastern part of Atlantic Ocean with a wide distribution range, extending from the Spanish coast to Angola, and occurring also around the Madeira, Canary Islands, Azores, and Cape Verde islands (Ben Tuvia and McKay 1986). This subtropical species, which naturally entered the Mediterranean Sea through the Straits of Gibraltar in the first half of the nineteenth century, has spread to almost all Mediterranean coasts (Bodilis et al. 2013). The bastard grunt reached, with a relatively fast spread (50 years), the far eastern coasts of the Mediterranean Sea (Lebanon, Egypt, Israel) following the general circulation current (see references in Bodilis et al. 2013) and is presently reported, and presumably also well established, in some localities (Chakroun-Marzouk and Ktari 2006, Kapiris et al. 2008). In the Tunisian marine waters, the distribution of this species stretches from the northern to the southern coasts, where it is common at the depths between 50 and $100 \mathrm{~m}$ (Azzouz 1974). Despite its regular presence on the fish markets, the value of total catches of the bastard grunt are still unknown. On the other hand, the species was slower to reach the northern part of the Mediterranean

\footnotetext{
* Correspondence: Inès Chater, Université de Tunis El Manar, Faculté des Sciences de Tunis, UR11ES12 Biologie de la Reproduction et du Développement animal, Laboratoire d'Ichtyologie fondamentale et appliquée, 2092 Tunis EL Manar (Tunisie), phone: +216 225958 17, fax: +216 71 87 16 66, e-mail: (ICH) ineschater13@gmail.com, (AR) romdhani.ahlem@gmail.com, (JLD) jean.louis.dufour@ifremer.fr, (KM) kelig.mahe@ifremer.fr, (PF) patrice.francour@unice.fr, (NCHM)knn.marzouk@gnet.tn.
} 
basin and/or is still not considered as a well-established species (Riera et al. 1993, Gavagnin et al. 1994, Serena and Silvestri 1996, Kapiris et al. 2008, Pastor et al. 2008). According to Bodilis et al. (2013) this pattern of distribution may be due to a recent warming of the western Mediterranean waters or to a greater influx of waters from the Atlantic through the Straits of Gibraltar.

Although the bastard grunt has a wide geographic distribution in the Mediterranean, few biological data are available. Among the topics investigated were: parasite fauna (Euzet and Ktari 1970), reproduction and length-weight relations (Chakroun-Marzouk and Ktari 1995, 2006, Kapiris et al. 2008), reproduction and feeding habits (Fehri-Bedoui and Gharbi 2008), fish condition, and reproductive biology (Villegas-Hernández et al. 2015). Only two studies deal with life history and growth of Pomadasys incisus in the Canary Islands (Pajuelo et al. 2003a, 2003b), but the growth of this species is unknown in the Mediterranean Sea. Therefore, the presently reported study represents the first attempt to determine the age and growth of the bastard grunt in the southern Mediterranean. The study has been conducted to provide growth parameters characteristics and to define the bastard grunt life span, condition factor, and length and age at first sexual maturity in order to contribute to a better management of its fishery in Tunisia.

\section{MATERIAL AND METHODS}

Fish sampling. A total of 515 specimens of Pomadasys incisus were obtained from the landings of the small-scale artisanal fisheries of the Gulf of Tunis. The specimens were randomly collected, on a monthly basis, from October 2008 to September 2010. Each individual was measured to the nearest $1 \mathrm{~mm}$ for total length (TL), weighed to the nearest $1 \mathrm{~g}$ for total weight $(W)$, and sexed throughout a macroscopical examination of the gonads.

Length-weight model. The fish length-weight relation is described by the power function

$$
W=a \times \mathrm{TL}^{b}
$$

where $W$ is the total weight $[\mathrm{g}]$ and TL the total length [cm]. The regression coefficients - the intercept $(a)$ and the slope $(b)$, were calculated for the whole sample and separately for each sex. The comparison of the log-transformed curves between males and females was carried out using a covariance analysis (ANCOVA).

Otolith preparation. For each specimen, sagittal otoliths were removed, cleaned, and stored dry in numbered paper envelopes. The whole otoliths were immersed in a blackbottom watch glass containing water in order to increase contrast between rings. They were viewed under reflected light with a binocular microscope coupled to a high-resolution camera, itself connected to a central processing unit (TNPC software ${ }^{*}$ ). Distances from otolith core to rostrum $\left(R_{\mathrm{o}}\right)$ and to each translucent zone $\left(R_{n}\right)$ were measured to the nearest $0.01 \mathrm{~mm}$ (Fig. 1). Counts of the annual growth increments were made by two readers, without reference to fish length and sex to avoid subjectivity effect on age estimations. To minimize observation errors, only coincident readings were accepted.

Validation and estimation of age. To validate seasonality and to determine the formative period of the translucent zone, the marginal increment ratio analysis was used (Jearld 1983). Thus the monthly estimates of the MIR were carried out on the entire otolith sample and followed over time. Marginal increment ratio (MIR) was then calculated by the following formula:

$$
\operatorname{MIR}=\left(R_{\mathrm{o}}-R_{n}\right) \times\left(R_{n}-R_{n-1}\right)^{-1}
$$

where $R_{0}, R_{n}$, and $R_{n-1}$ are respectively the radius, the radius of the last-, and the next-to-last growth rings [mm].

The Kruskal-Wallis test was used to test the homogeneity of MIR among months followed by a Student-Newman-Keuls test (SNK) after null hypothesis rejection. Correlation between MIR and temperature was tested using the Spearman's rank correlation coefficient $\left(r_{\mathrm{s}}\right)$. The mean seawater temperature data were supplied by the National Institute of Meteorology of Tunisia*.

Once the timing of ring formation was validated by the marginal increment ratio analysis and after the annual periodicity was confirmed, each fish was assigned to an age class beginning with the date of capture, the period of the translucent zone formation, and considering 1 July as the start of age class 0 , since the peak of spawning of $P$. incisus occurs at that period (Chakroun-Marzouk and Ktari 2006).

The Index of average percentage error (IAPE) was calculated to evaluate the precision of the age determinations between the two readers (Beamish and Fournier 1981). Campana (2001) indicates that an IAPE of $5 \%$ or below is acceptable.

Growth model. The relation between the radius of the otolith $\left(R_{\mathrm{o}}\right)$ and the length of fish (TL) was estimated as a linear function between $\log (\mathrm{TL})$ and $\log \left(R_{\mathrm{o}}\right)$. The age growth was described by the von Bertalanffy model. The von Bertalanffy growth function (VBGF) was fitted to an

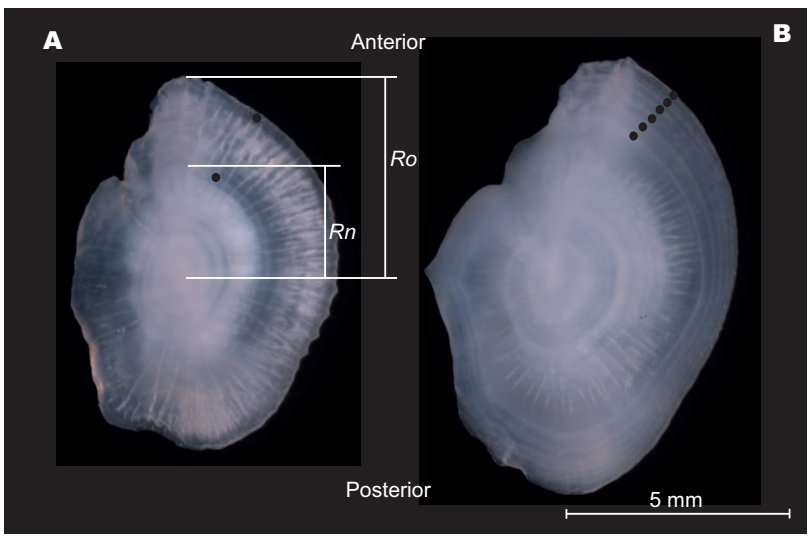

Fig. 1. Sagittal otoliths of bastard grunt, Pomadasys incisus, from the Gulf of Tunis; A, otolith with 2 annuli $(\mathrm{TL}=17.1 \mathrm{~cm})$; and $\mathbf{B}$, otolith with 6 annuli $(\mathrm{TL}=20.9 \mathrm{~cm})$; $R_{\mathrm{o}}=$ otolith radius, $R_{\mathrm{n}}=$ distance from the nucleus to the last growth increment

\footnotetext{
${ }^{*}$ www.tnpc.fr.

* www.meteo.tn
} 
estimated length-at-age data set using the FISHPARM program of the FSAS statistical package (Saila et al. 1988), applying the Marquardt's algorithm for nonlinear least squares parameter estimation.

The growth performance index $\Phi$ ' of Munro and Pauly (1983) was calculated by the equation

$$
\Phi^{\prime}=2 \log \mathrm{TL}_{\infty}+\log k
$$

where $\mathrm{TL}_{\infty}$ is asymptotic total length at which growth is zero and $k$ is the growth rate, with the objective to compare growth rates of $P$. incisus from different fishing areas.

Maturity and condition. The length at first maturity $\left(\mathrm{TL}_{50}\right.$, length at which $50 \%$ of the fish are mature) was estimated as the proportion of mature fish (PMF) in each fish class and was determined from the logistic function (Saila et al. 1988): $\mathrm{PMF}=1 \times\left(1+e^{-b \times(\mathrm{TL}-\mathrm{TL} 50)}\right)^{-1}$

where PMF is the proportion of mature fish for the length $\mathrm{TL}, b$ is the slope of the maturity curve, and $\mathrm{TL}_{50}$ is the size at which $50 \%$ of fish are mature. The function was fitted to the data, applying the Marquardt's algorithm for non-linear least square regression. Multivariate analysis (Hotelling's test) was used to compare the logistic model parameter estimates for males and females.

Fulton condition factor $K$ (Fulton 1904) was calculated monthly and for each age group, using the equation:

$$
K=100 W \times \mathrm{TL}^{-b}
$$

where $W$ is the total weight, TL is the total length, and $b$ is the regression parameter (the slope) of the length-weight relation.

Statistical analysis and comparison. All statistical analyses were performed with STATISTICA ${ }^{\circledR}$ software and the program FISHPARM ${ }^{\circledR}$ of the statistical package FSAS (Saila et al. 1988). The data are presented as the mean \pm standard error of the mean $(\mathrm{SE})$. For sex ratio deviations from $1: 1$ null hypothesis were statistically tested by the chi squared analyses. In all statistical tests, rejection of the null hypothesis was based on $\alpha=0.05$.

\section{RESULTS}

Sample characteristics and length-weight relation. The sex ratio of males (156) and females (338) was $1: 2.17$ and differed significantly from $1: 1\left(\chi^{2}=67.05 ; n=494\right.$, $P<0.05)$. Total length and weight frequency distributions of both sexes and unsexed fish were pooled and summarized in Fig. 2a and 2b. Males ranged in size from 14.0 to $21.4 \mathrm{~cm} \mathrm{TL}$ and females from 14.1 to $23.2 \mathrm{~cm}$ TL. The mean TL of males $(\mathrm{TL}=17.4 \pm 0.1 \mathrm{~cm})$ was significantly different (Mann-Whitney $U$ test; $n=494 ; P=2.10^{-6}$ ) from that of females $(\mathrm{TL}=18.2 \pm 0.1 \mathrm{~cm})$. Individuals of undetermined sex were 13.8 and $17.6 \mathrm{~cm}$ long (TL). The total weight of fish was between 34.0 and $146.0 \mathrm{~g}$ $(W=70.2 \pm 1.4 \mathrm{~g})$ for males and between 33.0 and $177.0 \mathrm{~g}$ $(W=79.8 \pm 1.4 \mathrm{~g})$ for females. It was significantly different between the two sexes (Mann-Whitney $U$ test; $n=494$; $P=11.10^{-5}$ ). Total weight of unsexed fish varied between 34.0 and $59.0 \mathrm{~g}$.

Length-weight regression parameters estimated for males, females, and the whole sample are presented in Table 1. For males, females, and when all individuals were pooled together, a positive allometry was observed. There were no statistically significant differences in the slopes between males and females (ANCOVA, $n=494$, $P>0.05)$. However, the intercepts were significantly different (ANCOVA, $n=494, P<0.05$ ).

Age validation and periodicity of the annulus formation. The lowest values of the monthly mean marginal increments (MI) were registered from January to March

Parameters of the length-weight relation of bastard grunt, Pomadasys incisus, determined

Table 1

\begin{tabular}{|c|c|c|c|c|c|c|c|c|}
\hline \multirow{2}{*}{ Area studied } & \multirow{2}{*}{ Reference } & \multirow{2}{*}{ Sex } & \multirow{2}{*}{$n$} & \multirow{2}{*}{$\begin{array}{c}\text { Total } \\
\text { length }[\mathrm{cm}]\end{array}$} & \multicolumn{4}{|c|}{ Length-weight relation } \\
\hline & & & & & $a$ & $b$ & SE of $b$ & $r^{2}$ \\
\hline Iskenderun Bay & Can et al. 2002 & $M+F$ & 106 & $13.4-21.2$ & $46.10^{-4}$ & 2.60 & 0.80 & 0.91 \\
\hline \multirow[t]{3}{*}{ Gulf of Tunis } & $\begin{array}{l}\text { Chakroun-Marzouk } \\
\text { and Ktari } 2006\end{array}$ & M & 328 & $13.1-24.7$ & $15.10^{-4}$ & 2.96 & & 0.93 \\
\hline & & $\mathrm{F}$ & 819 & $12.4-25.2$ & $11.10^{-4}$ & 3.07 & & 0.90 \\
\hline & & $M+F$ & 1323 & $11.3-25.2$ & $11.10^{-4}$ & 3.08 & & 0.92 \\
\hline N-E Mediterranean & Sangun et al. 2007 & $M+F$ & 23 & $11.9-19.0$ & $20.10^{-4}$ & 2.83 & 0.16 & 0.97 \\
\hline Badagry Creek (Nigeria) & Agboola and Anetekhai 2008 & $M+F$ & 22 & $8.0-22.6$ & $19.10^{-4}$ & 2.88 & & 0.99 \\
\hline \multirow[t]{2}{*}{ Gulf of Tunis } & Fehri-Bedoui and Gharbi 2008 & M & 207 & $11.9-23.6$ & $19.10^{-4}$ & 2.79 & & 0.84 \\
\hline & & $\mathrm{F}$ & 250 & $13.5-24.0$ & $13.10^{-4}$ & 2.92 & & 0.83 \\
\hline Aegean Sea & Kapiris et al. 2008 & $\mathrm{M}+\mathrm{F}$ & 39 & $14.0-26.7$ & $5.10^{-6}$ & 3.18 & & 0.96 \\
\hline Atlantic Spanish coast & Mata et al. 2008 & $M+F$ & & & & 2.96 & & \\
\hline \multirow[t]{3}{*}{ Gulf of Tunis } & Presently reported study & M & 156 & $14.0-21.4$ & $75.10^{-4}$ & 3.32 & 0.08 & 0.92 \\
\hline & & $\mathrm{F}$ & 338 & $14.1-23.2$ & $39.19^{-4}$ & 3.41 & 0.05 & 0.93 \\
\hline & & $\mathrm{M}+\mathrm{F}$ & 515 & $14.0-23.2$ & $49.10^{-4}$ & 3.33 & 0.04 & 0.93 \\
\hline
\end{tabular}
in the presently reported study and reported by other authors from different study areas

$n=$ sample size; length-weight relation parameters: $a=$ intercept, $b=$ slope, SE of $b=$ standard error of the slope $b$, $r^{2}=$ coefficient of determination, $\mathrm{M}=$ male, $\mathrm{F}=$ female. 
(Kruskal-Wallis test, $P<0.05$, SNK, $P<0.05$ ) (Fig. 3). Afterwards, the marginal increments increased throughout the spring and summer months and started to decline again in October. Therefore, only one annulus was formed each year, annulus deposition occurred during the late winter and early spring. Significant correlation was found between mean MI values and sea surface temperature $\left(r_{\mathrm{s}}=0.94, n=12, P<0.05\right)$.

Age accuracy and precision. Among the total otoliths examined, $474(92.0 \%)$ were easily used for age estimation, 4 were broken and 37 provided different age estimations across readings and were then excluded from the analysis; for the latter otoliths, age readings never disagreed more than one year. The index of average percent error (IAPE) value was low $1.3 \%$ indicating a good reproducibility between readers and readings.

Otolith size and fish size relation. The relation between fish length (TL) and otolith radius $\left(R_{\mathrm{o}}\right)$ fitted to a linear model. The two variables were correlated $(r=0.864$, $P<0.01)$. The value of the slope $b$ was not significantly different from 1 (Student's $t$-test, $P>0.05$ ); thus, an isometric relation was recorded.

Age and growth. The results of otolith reading are provided in Tables 2 and 3. Age of males and females ranged respectively between 1 and 7 years $(3.09 \pm 0.11)$ and between 1 and 8 years $(3.47 \pm 0.09)$. Regardless of the age group, the females were always significantly more numerous than the males (all $\chi^{2}, P<0.05$ ). Very few fish older than 5 years were captured over the entire sampling period. Indeed, approximately $67 \%$ of aged specimens were among 2 and 4 years, with a modal age of 2 years. Individuals grew faster during the first year of life, attaining approximately $65 \%$ of their maximum length.

The von Bertalanffy growth function was fitted to age and length data for all the samples (Fig. 4). The estimated growth parameters were: $\mathrm{TL}_{\infty}=23.9 \pm 1.28 \mathrm{~cm}, k=0.186$ \pm 0.12 year $^{-1}$ and $t_{0}=-4.62 \pm 0.12$ year. The growth in weight described by a von Bertalanffy function was: $W=193.7 \times\left(1-e^{-0.186 \times(t+4.62)}\right)^{3.335}$.

Condition factor. Differences between mean condition factor of males and females were not significant (Mann-Whitney $U$ test, $P>0.05$ ) that is why the coeffi-

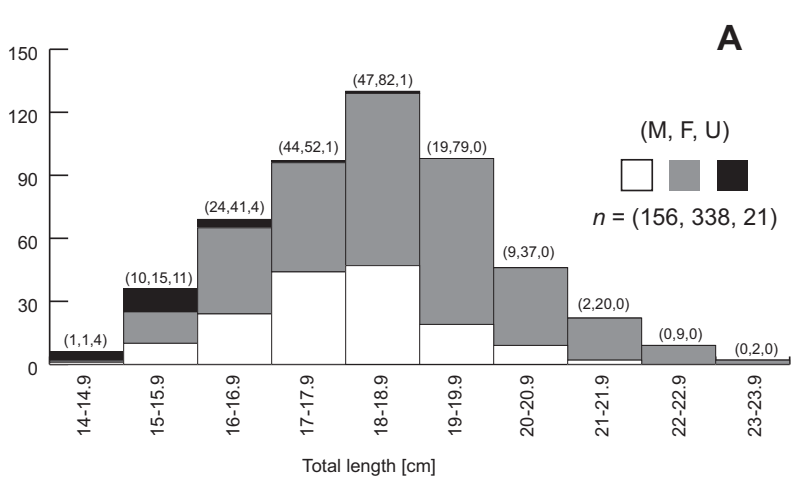

cient was calculated for the whole population (Table 2). Additionally, seasonal variations of the condition factor were given (Fig. 5). In general, monthly variations showed a peak during the summer. Differences between values of $K$ according to months, especially in May-August, were statistically significant (Kruskal-Wallis test, $P<0.05$, SNK, $P<0.05$ ).

Length and age at first maturity. Length at first maturity was significantly similar (Hotelling's $T^{2}$ test, $P>0.05$ ) for males $\left(\mathrm{TL}_{50}=16.6 \mathrm{~cm}\right)$ and females $\left(\mathrm{TL}_{50}=16.8 \mathrm{~cm}\right)$. For pooled sexes, $\mathrm{TL}_{50}$ was $16.6 \mathrm{~cm}$. This size corresponds to an age of about 2 years.

\section{DISCUSSION}

The oldest age estimate obtained in this study was 8 years and the stacking phenomenon of growth rings towards the otolith margin was not evident. Therefore, owing to the translucency of the otolith, its observation provided an easy age estimation without having to prepare thin section. Pomadasys incisus shows the common ring pattern of temperate teleost fishes with concentric growth marks composed of an opaque and a hyaline zone, corresponding to rapid and slow growth, respectively. The opaque zone of the first annulus was larger than the translucent one. After the second ring, the two components of the annulus had the same width, although their width slowly decreased towards the otolith margin. The value of the IAPE suggests that the ageing precision levels obtained are in agreement with the reference point values indicated by Campana (2001).

The evidence of the annual basis of ring formation is an obvious component of any age and growth study using calcareous structures (Campana 2001). Marginal increment analysis demonstrates that one annulus is laid down annually. Pajuelo et al. (2003a, 2003b) studied age of Pomadasys incisus in Canary Islands and reported a similar periodicity. In the Gulf of Tunis, dark slow translucent growth zone (organic-rich component) is deposited in winter while clear fast opaque zone (calcium-rich component) is deposited in summer. The formation of alternating translucent and opaque zones in the otoliths is controlled by a combination of endogenous and environmental fac-

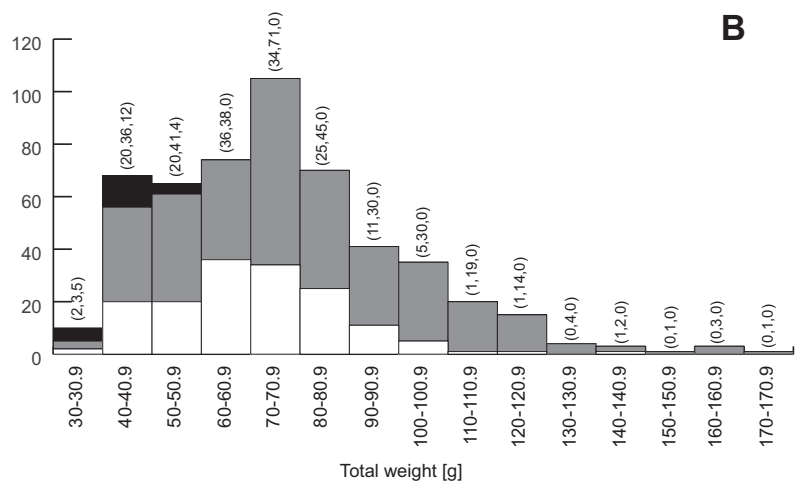

Fig. 2. Frequency distribution of total length (TL) (A) and total weight $(W)(\mathbf{B})$ for males, females, and undetermined individuals of bastard grunt, Pomadasys incisus, collected in the Gulf of Tunis; $\mathrm{M}=$ males, $\mathrm{F}=$ females, $\mathrm{U}=\mathrm{unde-}$ termined fish 
tors (Beckman and Wilson 1995) which vary at different ages and between sexes. The physiological changes are produced mainly by the influence of temperature, photoperiodism, reproductive cycle, and food availability (Pannella 1980). In the Gulf of Tunis, the fast growth in the otoliths of $P$. incisus, occurs in summer (August) when the sea temperature reaches its highest values (29.0), and the slow growth - in winter (February) when the sea water reaches its lowest values $\left(12.7^{\circ} \mathrm{C}\right)$. This significant rise in water temperature could involve changes in the metabolic activity of the individuals during spring and summer and could be the main factor responsible for opaque zone deposition. Similar findings have been reported for Pomadasys species, including $P$. incisus in Canary Islands (Pajuelo et al. 2003b) and Pomadasys kaakan (Cuvier, 1830) in Kuwaiti waters (Al-Husaini et al. 2001).

The significant correlation found between TL and otolith radius $\left(R_{\mathrm{O}}\right)$ indicates that this structure is useful for estimating age and for reconstructing past growth history of fishes (Francis 1990). Results indicate that otoliths of bastard grunt have an isometric growth.

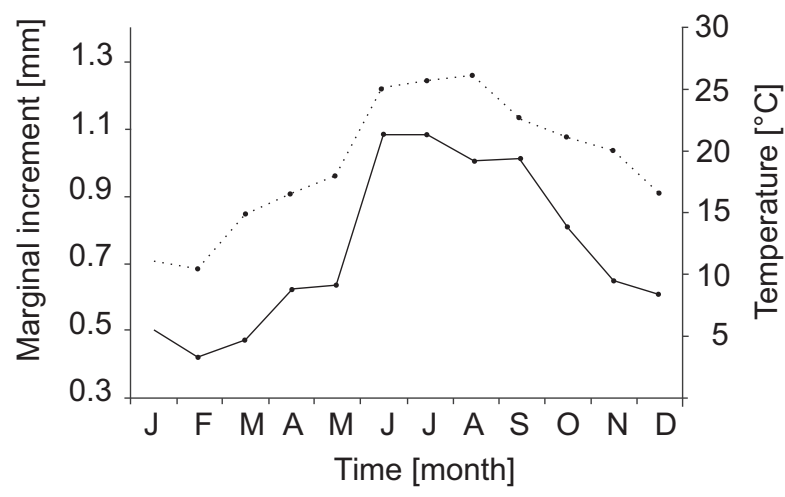

Fig. 3. Mean monthly marginal increment for bastard grunt, Pomadasys incisus, from the Gulf of Tunis and the associated sea surface mean temperature (temperature data supplied by the National Institute of Meteorology of Tunisia); Continuous line for marginal increment, dashed line for temperature

Table 2

Fish number in individual length classes and age groups of bastard grunt, Pomadasys incisus, from the Gulf of Tunis

\begin{tabular}{|c|c|c|c|c|c|c|c|c|}
\hline \multirow{2}{*}{ Size $[\mathrm{cm}]$} & \multicolumn{8}{|c|}{ Age group [year] } \\
\hline & 1 & 2 & 3 & 4 & 5 & 6 & 7 & 8 \\
\hline 14 & 6 & & & & & & & \\
\hline 15 & 26 & 7 & & & & & & \\
\hline 16 & 18 & 45 & 2 & & & & & \\
\hline 17 & 4 & 48 & 24 & 10 & & & & \\
\hline 18 & & 18 & 52 & 36 & 13 & & & \\
\hline 19 & & & 22 & 36 & 29 & 5 & & \\
\hline 20 & & & 4 & 12 & 16 & 11 & & \\
\hline 21 & & & & 4 & 6 & 5 & 4 & 1 \\
\hline 22 & & & & & 1 & 2 & 4 & 2 \\
\hline 23 & & & & & & 1 & & \\
\hline
\end{tabular}

Table 3

Morphometric parameters in individual age groups of bastard grunt, Pomadasys incisus, of the Gulf of Tunis

\begin{tabular}{ccccccccc}
\hline \multirow{2}{*}{ Parameter } & \multicolumn{10}{c}{ Age group [year] } \\
\cline { 2 - 9 } & 1 & 2 & 3 & 4 & 5 & 6 & 7 & 8 \\
\hline TL Mean \pm SE & $15.6 \pm 0.1$ & $17.1 \pm 0.1$ & $18.2 \pm 0.1$ & $19.1 \pm 0.10$ & $19.9 \pm 0.2$ & $20.6 \pm 0.2$ & $21.2 \pm 0.2$ & $21.5 \pm 0.3$ \\
Range & $14.0-17.4$ & $14.8-18.4$ & $16.2-20.3$ & $16.9-21.4$ & $17.7-22.1$ & $18.6-23.2$ & $20.6-22.3$ & $21.4-22.4$ \\
$W$ Mean \pm SE & $55.2 \pm 1.9$ & $76.6 \pm 1.1$ & $91.6 \pm 1.4$ & $109.1 \pm 1.7$ & $125.5 \pm 2.7$ & $142.3 \pm 5.1$ & $159.4 \pm 5.8$ & $168.5 \pm 6.7$ \\
Range & $33.0-88.0$ & $44.0-93.0$ & $78.0-128.0$ & $84.0-121.0$ & $86.0-177.0$ & $124.0-167.0$ & $151.0-169.0$ & $157.0-175.0$ \\
$k$ Mean \pm SE & $1.29 \pm 0.02$ & $1.25 \pm 0.01$ & $1.30 \pm 0.01$ & $1.30 \pm 0.01$ & $1.31 \pm 0.01$ & $1.31 \pm 0.02$ & $1.29 \pm 0.03$ & $1.29 \pm 0.05$ \\
Range & $1.04-1.66$ & $1.05-1.63$ & $1.11-1.60$ & $1.06-1.50$ & $1.01-1.58$ & $1.08-1.53$ & $1.18-1.44$ & $1.16-1.37$ \\
$n$ & 54 & 118 & 104 & 98 & 65 & 24 & 8 & 3 \\
Sex ratio M : F & $1: 1.70$ & $1: 2.28$ & $1: 1.74$ & $1: 1.72$ & $1: 3.33$ & $1: 10.33$ & $1: 7.00$ & - \\
ALI & - & 1.5 & 1.1 & 0.9 & 0.8 & 0.7 & 0.6 & 0.3 \\
\hline
\end{tabular}

$\mathrm{TL}=$ total length $[\mathrm{cm}], W=$ total weight $[\mathrm{g}], k=$ condition factor, $\mathrm{M}=$ male, $\mathrm{F}=$ female, $\mathrm{SE}=$ standard error of the mean, $n=$ sample size, ALI = annual length increment $[\mathrm{cm}]$. 
The estimated value of the theoretical maximum length obtained in this study $(23.9 \mathrm{~cm})$ is slightly higher than the size of the largest fish sampled $(23.2 \mathrm{~cm}$ TL). Pomadasys incisus increased rapidly in length until attaining sexual maturity at the age of about 2 years. This change in the growth rate, after sexual maturity, may be attributed to the use of available energy for reproduction instead of somatic growth (Pajuelo et al. 2003a). The decrease in growth rate was observed in the otoliths as a decrease in the width of the alternating annuli. The growth coefficient value indicates a relatively fast reach of maximal size, which is rather characteristic of a moderately short life cycle species.

The comparison of Pomadasys incisus growth parameters from different areas shows substantial discrepancies (Table 4). These differences can be attributed to differences in the environmental conditions of the different areas or to a bias introduced by methodological approaches (ageing and statistical analyses procedures, length composition of the sample). Pomadasys incisus of the Gulf of Tunis has the lowest $\mathrm{TL}_{\infty}$ and growth coefficient $(k)$. In the two studies of Pajuelo et al. (2003a, 2003b), estimates of growth parameters were similar because the samples were similar in size range and in number of individuals treated; although, they used the mean back-calculated length at age relation for the first study and the mean length at age for the second one. Thus, the significant differences found in growth rate and $\mathrm{TL}_{\infty}$ values may be, partly, due to differences in the size range of sampled fish; alternatively, they may indicate the existence of different populations of the same species. Maximum total length recorded in Canary Islands (TL $=30.4 \mathrm{~cm}$ ) (Pajuelo et al. 2003a, 2003b) was clearly higher than that of the biggest individual captured in our coasts $(23.2 \mathrm{~cm} \mathrm{TL})$. The growth performance index $(\Phi ')$ values indicate also a higher growth in Canary Islands (Pajuelo et al. 2003a, 2003b).

The slope $(b)$ values of the length-weight relation in both sexes ( $b=3.32$ for males, $b=3.41$ for females) and for the entire sample $(b=3.33)$ showed that the growth of Pomadasys incisus is hyperallometric. This results are different from those found by Chakroun-Marzouk and Ktari (2006) (isometric growth), and Fehri-Bedoui and Gharbi (2008)

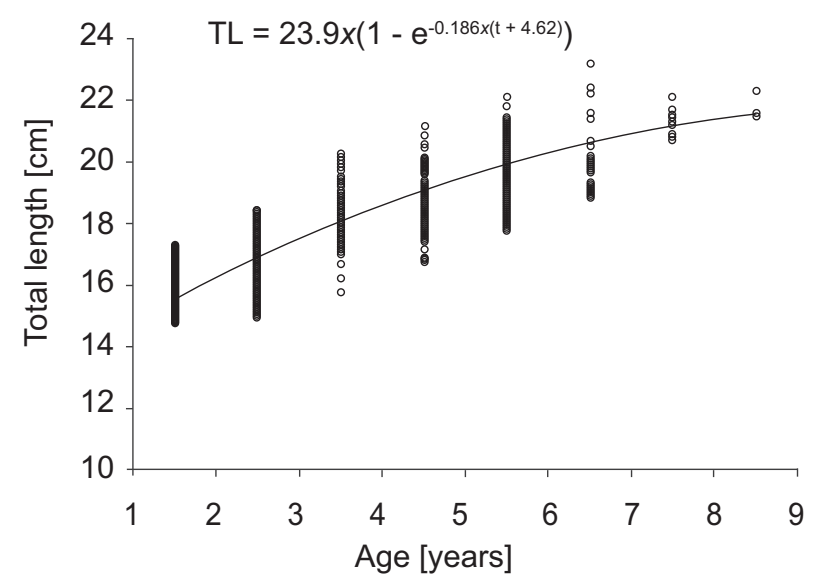

Fig. 4. The von Bertalanffy growth curve of bastard grunt, Pomadasys incisus, in the Gulf of Tunis fitted to the data $(n=474)$

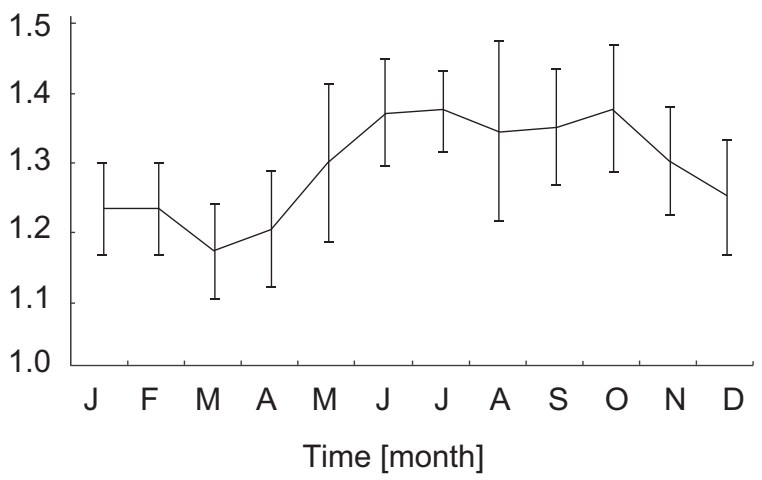

Fig. 5. Monthly variations in mean condition factor $(K)$ ( \pm standard error of the mean) for bastard grunt, Pomadasys incisus, from the Gulf of Tunis $(n=474)$

Table 4

Von Bertalanffy growth parameters and growth performance of bastard grunt, Pomadasys incisus, from different geographical areas

\begin{tabular}{lccc}
\hline & & Area studied & \\
\cline { 2 - 4 } & Canary Islands & Canary Islands & Gulf of Tunis \\
\hline Reference & Pajuelo et al. 2003a & Pajuelo et al. 2003b & Presently reported study \\
$\mathrm{TL}_{\infty}(\mathrm{cm})$ & 31.5 & 33.2 & 23.9 \\
$k\left(\right.$ year $\left.^{-1}\right)$ & 0.217 & 0.271 & 0.186 \\
$t_{0}$ (year) & -1.733 & -0.710 & -4.62 \\
$n$ & 812 & 813 & 474 \\
Total length [cm] & $10.3-30.4$ & $10.3-30.4$ & $14.0-23.2$ \\
Age range [year] & $0-7$ & $0-7$ & $1-8$ \\
$\Phi^{\prime}$ & 2.33 & 2.47 & 2.04 \\
\hline
\end{tabular}

$\mathrm{TL}_{\infty}=$ asymptotic length, $k=$ growth coefficient, $t_{0}=$ theoretical age at zero length, $n=$ sample size, $\Phi^{\prime}=$ growth performance index. 
$(b<3)$ in the same area. Furthermore, for the same size, males are heavier than females. As seen in Table 1 , our $b$ values were found to be close to estimates in the Aegean Sea (Kapiris et al. 2008) and in the gulf of Cadiz (Torres et al. 2012) but different from those found along the Turkish coasts (Can et al. 2002, Sangun et al. 2007), in the Badagry Creek (Agboola and Anetekhai 2008), and along the Spanish coasts (Mata et al. 2008). The length-weight relation is a practical index of the condition of fish and its parameter $b$ may vary over the year according to several exogenous and endogenous factors such as food availability, feeding rate, health, sex, gonad development, spawning period, and the preservation techniques (Bagenal and Tesch 1978). Subsequently, if these length-weight relations were obtained throughout a complete annual cycle, as in the presently reported study, the calculated parameters would be, then, more appropriate.

The variations of the condition factor in relation with age showed that both sexes had the same condition since no significant differences were recorded. Our findings in the mean monthly condition factor for males $(1.17<K<1.36)$ and females $(1.17<K<1.41)$ are similar to those estimated by Chakroun-Marzouk and Ktari (2006) (males: $1.11<$ $K<1.29$; females $1.13<K<1.32$ ) in the Gulf of Tunis. However, the condition of the sample studied by FehriBedoui and Gharbi (2008), in the same area, was higher (males: $1.67<K<2.21$; females $1.16<K<1.60$ ). Lowest values of the condition coefficient were recorded in winter, during the slow growth season. The fitness of bastard grunt does not seem to be affected by the reproduction period occurring in summer. Assuming that Pomadasys incisus is a thermophilic species (Kapiris et al. 2008), it has the highest condition when temperature increases.

The lengths at first sexual maturity $\left(\mathrm{TL}_{50}\right)$ estimated in this work (16.6 cm for males and $16.8 \mathrm{~cm}$ for females) were close to those given by Chakroun-Marzouk and Ktari (2006) (16.0 cm for males and $16.2 \mathrm{~cm}$ for females) in the Gulf of Tunis, but were higher than sizes recorded by Fehri-Bedoui and Gharbi (2008) (15.1 cm for males and $15.6 \mathrm{~cm}$ for females). Considering pooled sexes, $\mathrm{TL}_{50}$ $(16.6 \mathrm{~cm})$ was higher than that reported for colder water population inhabiting the north-western Mediterranean (14.9 cm) (Villegas-Hernández et al. 2015), but lower than the one in Canary Islands (18.3 cm) (Pajuelo et al. 2003b).

In the Gulf of Tunis, the age at maturity, for both sexes, is about 2 years and Pajuelo et al. (2003b) found that Pomadasys incisus attains sexual maturity at a similar age in Canary Islands. Indeed, variations in length at first maturity are closely related to total population abundance with maturation at a smaller size when population size is low (Morgan and Colbourne 1999). Temperature is assumed to affect only body size growth, so the temperature effects on maturation are indirect via life history optimization (Charnov and Gillooly 2004).

The bastard grunt was able to expand its range of distribution through various biological mechanisms, such early maturity, rapid growth during the first year of life, moderately short life span, ecological plasticity, and a high tolerance for unfavourable environmental conditions. Therefore, as reported by Villegas-Hernández et al. (2015), the plasticity of the life-history traits of Pomadasys incisus may allow this thermophilic species to respond to environmental pressures from the new habitats and might play an important role in the northward spread and successful establishment within the Mediterranean Sea.

The bastard grunt is now a well-established species along the Tunisian coast, regularly fished in coastal areas. The length at first maturity in Tunisia suggests that to sustain bastard grunt fisheries a minimal legal size of $16 \mathrm{~cm}$ has to be proposed. However, determining other parameters, like total and natural mortality, will lead to a better understanding of the long-term changes of the stock size in Tunisia.

\section{REFERENCES}

Agboola J.I., Anetekhai M.A. 2008. Length-weight relationships of some fresh and brackish water fishes in Badagry creek, Nigeria. Journal of Applied Ichthyology 24 (5): 623-625. DOI: $10.1111 / j .1439-0426.2008 .01079 . x$

Al-Husaini M., Al-Ayoub S., Dashti J. 2001. Age validation of nagroor, Pomadasys kaakan (Cuvier, 1830) (Family: Haemulidae) in Kuwaiti waters. Fisheries research 53 (1): 71-81. DOI: 10.1016/S0165-7836(00)00268-X

Azzouz A. 1974. Les fonds chalutables de la région nord de la Tunisie 2 : Potentialités de la pêche, écologie et répartition bathymétrique des poissons. Bulletin de l'Institut national scientifique et technique d'Océanographie et de Pêche de Salammbô 3 (1-4): 29-94.

Bagenal T.B., Tesch F.W. 1978. Age and growth. Pp. 101-135. In: Bagenal T.B. (ed.) Methods for assessment of fish production in fresh waters. IBH Handbook No. 3. Blackwell Scientific Publications, Oxford, UK.

Beamish R.J., Fournier D.A. 1981. A method for comparing the precision of a set of age determination. Canadian Journal of Fisheries and Aquatic Sciences 38 (8): 982-983. DOI: $10.1139 / \mathrm{f} 81-132$

Beckman D.W., Wilson C.A. 1995. Seasonal timing of opaque zone formation in fish otoliths. Pp. 27-43. In: Secor D.H., Dean J.M., Campana S.E. (eds.) Recent developments in fish otolith research. Vol. 19. The Belle W. Baruch Library in Marine Science, University of South Carolina Press, Columbia, SC, USA.

Ben Tuvia A., McKay R. 1986. Haemulidae. Pp. 858-864. In: Whitehead P.J.P., Bauchot M.-L., Hureau J.-C., Nielsen J., Tortonèse E. (eds.) Fishes of the north-eastern Atlantic and the Mediterranean. Vol. 2. UNESCO, Paris France.

Bodilis P., Crocetta F., Langeneck J., Francour P. 2013. The spread of an Atlantic fish species, Pomadasys incisus (Bowdich, 1825) (Osteichthyes: Haemulidae), within the Mediterranean Sea with new additional records from the French Mediterranean coast. Italian Journal of Zoology 80 (2): 273-278. DOI: $10.1080 / 11250003.2012 .730555$

Campana S.E. 2001. Accuracy, precision and quality control in age determination, including a review of the use and abuse of age validation methods. Journal of Fish Biology 59 (2): 197-242. DOI: $10.1111 / j .1095-8649.2001 . t b 00127 . x$ 
Can M.F., Başusta N., Çekiç M. 2002. Weight-length relationships for selected fish species of the small-scale fisheries off the south coast of İskenderun Bay. Turkish Journal of Veterinary and Animal Sciences 26 (5): 1181-1183.

Chakroun-Marzouk N., Ktari M.H. 1995. Données préliminaires sur la reproduction de Pomadasys incisus (Bowdich, 1825) (Pisces, Haemulidae) du golfe de Tunis. Rapport du Congrès de la CIESM No. 34.

Chakroun-Marzouk N., Ktari M.-H. 2006. Caractéristiques de la reproduction et de la croissance pondérale relative de Pomadasys incisus (Haemulidae) du golfe de Tunis. Cybium 30 (4): 333-342.

Charnov E.L., Gillooly J.F. 2004. Size and temperature in the evolution of fish life histories. Integrative and Comparative Biology 44 (6): 494-497.

DOI: $10.1093 / \mathrm{icb} / 44.6 .494$

Euzet L., Ktari M.H. 1970. Heteraxinoides hannibali n. sp. (Monogena, Polyopisthocotylea), parasite branchial de Pomadasys incisus (Bowdich, 1825) (Teleostei) dans le golfe de Tunis. Bulletin du Muséum National d'Histoire Naturelle 2e ser 41 (1): 269-279.

Fehri-Bedoui R., Gharbi H. 2008. Sex-ratio, reproduction and feeding habits of Pomadasys incisus (Haemulidae) in the Gulf of Tunis. Acta Adriatica 49 (1): 5-19.

Francis R.I.C.C. 1990. Back-calculation of fish length: a critical review. Journal of Fish Biology 36 (6): 883-902. DOI: $10.1111 /$ j.1095-8649.1990.tb05636.x

Froese R., Pauly D. (eds.) 2014. FishBase. [version 4/2014] http://www.fishbase.org

Fulton T.W. 1904. The rate of growth of fishes. 22nd Annual Report, Part III. Fisheries Board of Scotland, Edinburgh, Scotland.

Gavagnin P.S., Garibaldi F., Relini M. 1994. Segnalazione di Pomadasys incisus (Bowdich, 1825) (Osteichthyes, Haemulidae) in acque italiane. [Occurrence of Pomadasys incisus (Bowdich, 1825) (Osteichthyes, Haemulidae) in Italian waters.] Biologia Marina Mediterranea 1 (1): 285-286. [In Italian.]

Jearld A. 1983. Age determination. Pp. 301-324. In: Nielson L.A., Johnson D.L. (eds). Fisheries techniques. American Fisheries Society, Bethesda, MD, USA.

Kapiris K., Kallias E., Conides A. 2008. Preliminary biological data on Pomadasys incisus (Osteichthyes: Haemulidae) in the Aegean Sea, Greece. Mediterranean Marine Science 9 (2): 53-62. DOI: $10.12681 / \mathrm{mms} .132$

Mata A.J., Morales J.R., Márquez L. 2008. Weight-length relationships for 26 demersal fish species of the Spanish South-Atlantic coastal waters. Journal of Applied Ichthyology 24 (3): 330-333. DOI: $10.1111 / \mathrm{j} .1439-0426.2008 .01058 . x$

Morgan M.J., Colbourne E.B. 1999. Variation in maturity-atage and size in three populations of American plaice. ICES
Journal of Marine Science 56 (5): 673-688.

DOI: $10.1006 /$ jmsc. 1999.0487

Munro J.L., Pauly D. 1983. A simple method for comparing growth of fishes and invertebrates. Fishbyte 1 (1): 5-6.

Pajuelo J.G., Lorenzo J.M., Gregoire M. 2003a. Age and growth of the bastard grunt (Pomadasys incisus: Haemulidae) inhabiting the Canarian archipelago, northwest Africa. Fishery Bulletin 101 (4): 851-859.

Pajuelo J.G., Lorenzo J.M., Gregoire M., DomínguezSeoane R. 2003b. Life history of Pomadasys incisus (Osteichthyes, Haemulidae) in the Canarian archipelago. Scientia Marina 67 (2): 241-248.

DOI: $10.3989 /$ scimar.2003.67n2241

Pannella G. 1980. Growth patterns in fish sagittae. Pp. 519-560. In: Rhoads D.C., Lutz R.A. (eds.) Skeletal growth of aquatic organisms. Plenum Press, New York, NY, USA.

Pastor J., Astruch P., Prats E., Dalias N., Lenfant P. 2008. Premières observations en plongée de Pomadasys incisus (Haemulidae) sur la côte catalane française. Cybium 32 (2): 185-186.

Riera F., Pou S., Grau A.M. 1993. La ictiofauna. Pp. 263-644. In: Alcover J.A., Ballesteros E., Fornós J. (eds.). Història naturál de l'Arxipèlag de Cabrera. Monografies de la Societat d'Historia Natural de les Balears No. 2. Editorial Moll - CSIC, Palma de Mallorca, Spain.

Saila G.B., Recksiek C.W., Prager M.H. (eds.) 1988. Basic fishery science programs. A compendium of microcomputer programs and manual of operation. Developments in Aquaculture and Fisheries Science Vol. 18. Elsevier, Amsterdam, the Netherlands.

Sangun L., Akamca E., Akarl M. 2007. Weight-length relationships for 39 fish species from the north-eastern Mediterranean coast of Turkey. Turkish Journal of Fisheries and Aquatic Sciences 7 (1): 37-40.

Serena F., Silvestri R. 1996. First record of Pomadasys incisus (Haemulidae) in the northern Tyrrhenian Sea. Cybium 20 (4): 409-411.

Torres M.A., Ramos F., Sobrino I. 2012. Length-weight relationships of 76 fish species from the Gulf of Cadiz (SW Spain). Fisheries Research 127-128: 171-175.

DOI: 10.1016/j.fishres.2012.02.001

Villegas-Hernández J., Lloret J., Muñoz M. 2015. Climate-driven changes in life-history traits of the bastard grunt Pomadasys incisus (Teleostei: Haemulidae) in the north-western Mediterranean. Mediterranean Marine Science 16 (1): 21-30. DOI: $10.12681 / \mathrm{mms} .951$

Received: 19 August 2014

Accepted: 17 December 2014

Published electronically: 31 March 2015 